\title{
Utilization of Pine Needles for Development of Biobased Packaging Material
}

\author{
Leela Chauhan $^{1 *}$, P.K. Omre ${ }^{1}$, T.P. Singh ${ }^{2}$, Anil Kumar ${ }^{3}$ and A.K. Verma ${ }^{4}$ \\ ${ }^{1}$ Department of Post-Harvest Process and Food Engineering, ${ }^{2}$ Department of Farm \\ Machinery and Power Engineering ${ }^{3}$ Department of Food Science and Technology \\ ${ }^{4}$ Department of Biochemistry, Govind Ballabh Pant University of \\ Agriculture and Technology, Utrakhan-263145, India
}

*Corresponding author

\begin{tabular}{|l|}
\hline Ke y w o r d s \\
Bio-based, Pine \\
needles, Mechanical \\
properties
\end{tabular}

\section{Keywords}

Bio-based, Pine needles, Mechanical properties

10 September 2018

10 October 2018

\section{A B S T R A C T}

Pine trees are evergreen growing at average height of 15-45 $\mathrm{m}$ with a diameter of up to $1.2 \mathrm{~m}$. Pine needle are better known as Peerul in Uttrakhand. Pine needles, are adult leaves, which are green bundled in clusters with diameter of $1.5 \mathrm{~mm}$ and up to $20 \mathrm{~cm}$ length. Total pine needles available in India are 2.7 million tonnes per year (Pandey et al., 2011). Total pine needles available in India is 2.7 million tonnes per year, in India pine forests are widely found in the Indian Himalayan namely, Jammu \& Kashmir, Himachal Pradesh, Uttarakhand, Sikkim, Arunachal Pradesh, Meghalaya, Nagaland, Manipur, Mizoram, Tripura, and the hill regions of 2 states viz. Assam and West Bengal - comprising about 95 districts of the country where found pine needle in adequate quantity (Bisht et al., 2014). The availability of cellulose is more than $50 \%$ in pine needle thus its utilization for packaging material can be explored for value added utilization of pine needles (Lal et al., 2013). The utility of bio based (pine needles) packaging materials as a potential alternative choice for petrochemical derived plastic is imperative for environment waste management and health safety concern. Pine Needles fall on the forest floor and make a thick layer since their decomposition is slow due to prevalent climatic conditions. Thick layer of undecomposed needles is a major source of ground fires. Attempts have been made to use these needles to develop packaging materials for food materials. The experiments were performed on the varying amount of pine needles ranges from 50 to $100 \mathrm{~g}$ with constant particles size, varying amount of pulp prepared from waste cardboard from 10 to $50 \mathrm{~g}$ with constant plasticizer blended together. The prepared sample was compressed at constant pressure, holding time and temperature in order to obtained desirable mechanical properties of packaging material suitable for food packaging. 


\section{Introduction}

Food Packaging is art to change the perception or to attract the consumer. Packaging is the enclosure of products, items or packages in a wrapped pouch, bag, box, cup, tray, can, tube, bottle or other container form to perform one or more of the following functions: containment food commodity, protect from contamination due, preserve for future, communicate whatever food commodity inside. Conventional materials used for food packaging are polyethylene, polyvinyl chloride, polypropylene, glass etc.

Petroleum based plastics are dominantly used in food packaging industries due to their superiority properties such as mechanical and barrier properties. Irrespective of their numerous advantages, petroleum based packaging materials are cause detrimental effect on packed food as food comes in direct contact with packaging materials due to some chemical changes packaging material leach out harmful chemical into food and causes detrimental effect on packed food. Packaging material developed from non- biodegradable polymers also highly resistant to microbial attacks and thus persists in environment for several decades after disposal (Sanyang, et al., 2016). Every year in the state from 15 February to June 15 (Fire Season) damages the forest property on a large scale, according to Forest Department of India, Dehradun, a massive forest fire in 2017 engulfed 14.7 thousand acres of valuable forest area through 2,272 forest fire incidents in Uttrakhand, which resulted in the loss of crores of rupees and created various long-lasting ecological consequences. The fires damaged the fertile top layer of the soil and left a layer of pine needle litter that prevented rain water from being absorbed by the soil and contributed to early depletion of the groundwater cycle and stopped grass growth, thus depriving livestock of important food (DainikJagran, 2017).

\section{Materials and Methods}

In the present study, an effort was made to utilise pine needles for preparation of bio based packaging materials. The combination of pine needles as reinforcement material and waste newspaper as filler material were used for preparation of biobased packaging material.

\section{Pine needles}

The Pine needles will collected from pine trees at Forest of Nainital district, Uttrakahand. Needles fall from trees on the forest floor and make a thick layer since their decomposition is slow due to prevalent climatic conditions and presence of lignin (Pandey et al., 2011)

\section{Newspaper}

Waste newspaper used as filler material was dipped into hot water for $12 \mathrm{hr}$. The dipped newspaper was grounded into mixer for 10 minute to prepared pulp. The filler material used here is newspaper, which is the most common and easily available household asset. Loads of newspapers are dumped into oceans for disposal which come from 500,000 trees which are cut every week for their production and $88 \%$ of that is never recycled (Joshi et al., 2014).

\section{Measurement of moisture content}

Hot air single oven method (IS 4333-II, 1967) was used to determine moisture content of raw and dried pine needles respectively. Pine needles were prepared $5 \mathrm{~g}$ sample of three triplicate was taken in prior dried pert dish and placed in the hot air oven maintained at 130 \pm $5^{0} \mathrm{C}$ and left of 2 hour. After 2hour, dish was taken out of the oven, covered with its lid and put in to the desiccators to cool it down up to the room temperature. Moisture content of the 
sample was calculated using the following formula:

$\operatorname{MC}(\%$, d.b. $)=\frac{\left(W_{2}-W_{1}\right)-\left(W_{3}-W_{1}\right)}{\left(W_{3}-W_{1}\right)} \times 100$

Where,

$\mathrm{W}_{1}=$ Weight of the dish, $\mathrm{g}$

$\mathrm{W}_{2}=$ Weight of the sample before drying with dish, $g$

$\mathrm{W}_{3}=$ Weight of the sample after drying with dish,

\section{Grinding}

Dried pine needle was grinded into hammer mill (Make: Butex Engineering company, Kanpur).

\section{Sieving}

The grounded pine needles were separated on the basis of particles size. The particle size was selected as $\leq 0.7 \mathrm{~mm}$.

\section{Compressions}

The prepared sample was compressed through a compression moulding machine with constant pressure, temperature and holding time

\section{Ultimate tensile strength}

Ultimate tensile strength was done according to ASTM D 882 methodology, which is used for measuring UTS $\left(\mathrm{N} / \mathrm{mm}^{2}\right)$ and elongation properties of packaging in the form of thin sheeting. It is measure of material strength, the maximum pulling stress (force/cross-sectional area) that material can sustain before breakage.

\section{Water solubility}

The film solubility was determined according to the method of Gontard and Guibert by trimming the sample into small strips.

Small film strips were dried in an oven at $100^{\circ} \mathrm{C}$ for $24 \mathrm{~h}$ to a constant weight. Each dried sample was immersed in $100 \mathrm{~mL}$ of distilled water for $24 \mathrm{~h}$. Again film samples were then removed form water and re- dried at $100^{\circ} \mathrm{C}$ for $24 \mathrm{~h}$. Final weights were recorded and solubility were calculated as:

Solubility $\%=\frac{\text { Initial dry weight-Final dry weight }}{\text { Initial dry weight }} \times 100$

\section{Results and Discussion}

The packaging material was developed from grounded pine needles and pulp prepared from waste newspaper was analyzed its physicmechanical properties (Fig. 1).

\section{Mechanical properties}

\section{Tensile strength}

The tensile strength or ultimate strength of the material subjected to tensile loading. It is the maximum stress developed in a material in a tension UTM. Tensile strength is calculated by dividing the load at break by the original minimum cross- sectional area. The results are expressed in Megapascals (MPa). Maximum Tensile strength values depend on filler material and constant plasticizer because filler material form strong covalent bond thus tensile strength of prepared material increases from 0.088 to $0.820 \mathrm{MPa}$ (Thakur et al., 2010).

\section{Elongation}

The elongation of packaging material is the percentage increase in length that occurs before it breaks under tension. 
Fig.1 Flowchart for development
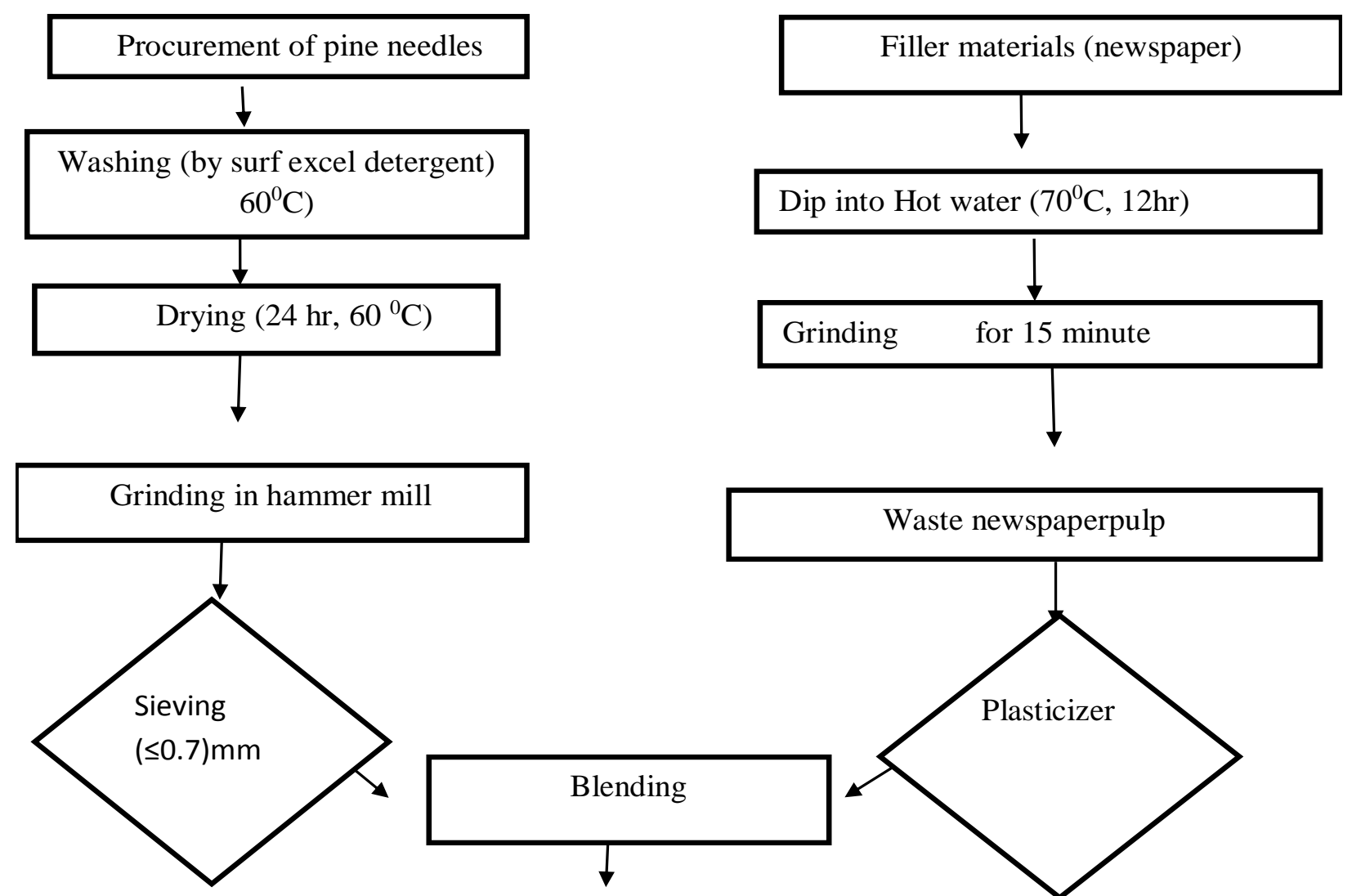

1

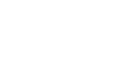


Table.1

\begin{tabular}{|l|l|l|l|l|l|l|l|}
\hline S.N & Pine $(\mathrm{g})$ & $\begin{array}{c}\text { Newspaper } \\
(\mathrm{g})\end{array}$ & $\begin{array}{c}\text { Total } \\
\text { mass }(\mathrm{g})\end{array}$ & $\begin{array}{c}\text { Tensile strength } \\
(\mathbf{M P a})\end{array}$ & $\begin{array}{c}\text { Elongation } \\
(\mathbf{m m} / \mathbf{m i n})\end{array}$ & $\begin{array}{c}\text { Solubility } \\
(\%)\end{array}$ & $\begin{array}{c}\text { Moisture } \\
\text { Absorbance (\%) }\end{array}$ \\
\hline $\mathbf{1}$ & 50 & 50 & 100 & 0.82 & 6.7 & 15.2 & 7.80 \\
\hline $\mathbf{2}$ & 60 & 40 & 100 & 0.71 & 4.2 & 12.6 & 6.90 \\
\hline $\mathbf{3}$ & 70 & 30 & 100 & 0.49 & 3.1 & 10.5 & 6.01 \\
\hline $\mathbf{5}$ & 80 & 20 & 100 & 0.32 & 2.4 & 8.1 & 5.08 \\
\hline 6 & 90 & 10 & 100 & 0.17 & 1.1 & 5.6 & 4.12 \\
\hline 7 & 100 & 0 & 100 & .088 & 0.03 & 3.2 & 3.01 \\
\hline
\end{tabular}

Elongation values of packaging material prepared from pine needles and a waste newspaper were increases as amount of pine increases and decreases 0.03 to $6.70 \mathrm{~mm} / \mathrm{min}$ (Thakur et al., 2010).

\section{Physical properties}

\section{Moisture absorbance}

Water absorbency can be a key attribute in packaging as strength and cohesion of materials can be impaired by too much water. Also, if then material were to be used in food packaging water absorption from food product would need to be needed. The moisture absorption patterns of material are shown in Table 1. As the amount of newspaper were decreases with respect to pine needles the solubility goes decreases due to the crosslinking of polysaccharides by lignin is an obstacle for water absorption to the cell wall (Sarkanen et al., 1971).

The study demonstrated the successful development of bio based packaging material from pine needles containing up $70 \%$ pine needles and 30\% newspaper and constant plasticizer. Compare the mechanical strength and physical strength with the prior developed material as apple crate the tensile strength and elongation were calculated as $0.47 \mathrm{MPa}$ and $4.859 \mathrm{~mm} / \mathrm{min}$ and the mechanical and physical strength newly developed packaging without filler material and plasticizer can't achieve desirable mechanical and physical properties.

\section{References}

ASTM, D., 1989. 882-88. Standard test methods for tensile properties of thin plastic sheeting. Annual book of ASTM standards, 8 .

Bisht, A.S., Singh, S. and Kumar, M. 2014. Pine needles a source of energy for Himalayan Region. Int.J. of Sci. \& Tech. Research., 3(12): 161-164.

Danik Jagran. 2017. Forest department's fire test starts from April. Newspaper Assessed on 03 A April 2017

Indian Standard Institution. 1967. Methods of analysis of food grains IS - 4333(partII).

Joshi, S., Sharma U and Goswami, G., 2014. Jodhpur, 23 February. 2015. Bio-plastic from waste newspaper. International Conference on Emerging Trends of Research in Applied Sciences and Computational Techniques.

Lal, P.S., Sharma, A. and Bist, V. 2013. Pine needle: An evaluation of pulp and paper making potential. J. For. Prod. Ind, 2(3): 42-47

Pandey, C.N. and Sujatha, D., 2011. Crop residues, the alternate raw materials of tomorrow for the preparation of composite board. Ind. Plywood Ind. Res. \& Training Institute. 56: 258-264. 
Sanyang, M. L., Sapuan, S. M., Jawaid, M., Ishak, M. R., \&Sahari, J. 2016. Effect of plasticizer type and concentration on physical properties of biodegradable films based on sugar palm (Arenga pinnata) starch for food packaging. $J$. of Food Sci. and Tech., 53(1): 326-336

Sarkanen, K.V. and Ludwig, C.H., 1971. Liguins. Occurrence, formation, structure, and reactions. New York; Wiley-Interscience.

Thakur, V.K. and Singha, A.S., 2010. Natural fibres-based polymers: Part IMechanical analysis of Pine needles reinforced biocomposites. Bulletin of Materials Science, 33(3):257-264.

\section{How to cite this article:}

Leela Chauhan, P.K. Omre, T.P. Singh, Anil Kumar and Verma, A.K. 2018. Utilization of Pine Needles for Development of Biobased Packaging Material. Int.J.Curr.Microbiol.App.Sci. 7(10): 1274-1279. doi: https://doi.org/10.20546/ijcmas.2018.710.143 